\title{
The Causal Link between Major Depressive Disorder, Suicidal Behavior and Filicide
}

\author{
Tănăsescu Gabriel \\ University of Craiova, Craiova, Romania, gabrieltanasescu@gmail.com
}

\begin{abstract}
This article describes the causal link between major depressive disorder, suicidal behavior and filicide. The filicide perpetrator is a person affected by major depressive disorder, the passage to the act does not manifest itself as an ordinary delinquent act, but has a specific etiology that sometimes involves suicidal behavior and conjugal crime. In 2014, Turhan Canli publishes in the Biology of Mood \& Anxiety Disorders a study on the re-conceptualization of the major depressive disorder as an infectious disease in which he suggests that major depression may result from a parasitic, bacterial or viral infection. Major depression and antisocial personality disorder can trigger the transformation of the criminal ego by overcoming the barrier of moral and religious inhibitions, emphasizing the transition to the crime. From a psychoanalytic and victimological point of view, the destructive attachment of the victims of marital crime that return to the aggressor after being physically abused is also analyzed.
\end{abstract}

KEYWORDS: antisocial personality, filicide, major depressive disorder, suicidal behavior, the victim of domestic violence

\section{Introduction}

The major depressive episode describes the disposition and condition of a person who has experienced at least four symptoms of low energy, feelings of futility or guilt, difficulty in thinking and making decisions, changes in body weight, sleeping disorders and psychomotor activity, the presence of the idea of death, as well as plans or attempts of suicide (DSM-IV-TR, 2003). The state of existential despair, anxiety, permanent irritability, frustration about insignificant events, contributes to the deterioration of the social behavior of the person suffering from major depressive disorder.

From a philosophical point of view (the theory of existentialism), the existential deterioration of being finds its explanation in the absurd and unfairness of the social world. Man's responsibility for his own world to build a positive project is overwhelming. Man is condemned to freedom (Sartre 2004) and carries on his shoulders the failure and glory of humanity. The story of a life, whatever it may be, is the story of a failure (Sartre 2004). The inability of the individual to achieve some of the proposed goals sometimes casts him in the absence of emotional imbalance. Poor management of emotions in interpersonal relationships, lack of discipline, effort and pleasure to be useful to the family and community lead to the absence of social commitments and a passive life at the risk of unacceptable isolation. In the middle of the family the individual with antisocial personality tries to find answers, tries to acquire a certain pleasant experience for his emotional instability. Impulsiveness and egocentrism are limited for a period of time by the protection of some patient parents, and later by a wife, a social partner who, without the power to reduce aggressive behavior, will quickly exhaust its intellectual and emotional resources to accept living with the marital afflictions. When personality traits become defective or inflexible, these sustainable patterns of perception, reporting and thinking about one's own person will lead to distress and deterioration in social behavior that is present throughout life (Costello 2017).

\section{Suicidal behavior}

Suicidal behavior can also be described as an obsessive concern of the individual over his existential failure and the lack of finding an alternative situation to solve the problems of his life. Mistrust in the moral nature of its unjustified being and the difficulty of managing social challenges push the person to conceive suicidal plans. An individual overwhelmed by the problems of life, without family support, without emotional stability, without professional preoccupations and social commitments, can turn to the suicidal act to get rid of any responsibility. The state of unhappiness, physical discomfort and lack of 
well-being, excessive anxieties and obsessive embarrassment become a suicidal risk for a person with moral and mental instability. Other factors that increase the risk of suicide: physical pain (especially in the case of chronic evolutionary disease without healing) supplemented by the lack of joy and spiritual life, the lack of a professional routine that actively maintains the pragmatic sense of being concerned with a useful and enjoyable existence. Schaffer and Rodolfa in the ICD-10-CM include as suicide risks the plan of suicide and the suicide verbal announcement, previous suicide attempts, depressive disorders, role played by rumination at the expense of problem-oriented thinking (Schaffer and Rodolfa 2019). Every year in the United States, nearly 45,000 people commit suicide, 13.4 out of 100,000 (Schaffer and Rodolfa 2019, citing Centers for Disease Control and Prevention, 2017).

\section{Major depressive disorder}

The presence of depressed mood can be deduced from the behavior of the individual affected in the family and socio-professionally environment, from attitude and language, from behavior and facial expression of the person (DSM-IV-TR, 2003). Descriptive elements of a major depressive episode: loss of interest or pleasure, significantly reducing sexual desire, lack of appetite (many individuals are in a state of depression is forced to eat), insomnia, changes in psychomotor, low energy and fatigue, feelings of worthlessness, damage ability to think, suicidal ideation, sadness, irritability, rumination; "Pathophysiology of major depressive episode of the disorder involves a number of neurotransmitters, including serotonin systems, norepinephrine, dopamine, acetylcholine and gamma-aminobutyric acid systems" (DSM-IV-TR, 2003).

In October 2014, Turhan Canli publishes in the Biology of Mood \& Anxiety Disorders an article supporting a reconceptualisation of the major depressive disorder as an infectious disease. The author believes that the etiology of major depression can also be explained by the possibility of a genetic link with the disease, the human body being an ecosystem for microorganisms, and the human genome hosts non-human exogenous sequences (Canli, 2014). Major depression may also be caused by parasitic infection (Toxoplasma gondii), bacterial (bacterial gastrointestinal) or viral (Borde disease virus - BDV). Through his study, Canli attempts to demonstrate that major depressive disorder is no longer to be regarded as merely an emotional disorder with endogenous causes that concern the inner self of the patient and his psychosocial problems. Major depression may be caused by an infection and should therefore be monitored as any parasite, bacterial or virus disease that could play a causal role in the etiology of major depressive disorder (Canli 2014). Meta-analysis of clinical trials and post-mortem studies have confirmed the presence of inflammatory markers in the brain of depressed or moody patients. The victims of female suicide had high levels of IL-4, and male suicide sufferers showed elevated IL-13 levels in the Brodmann area, a region of the brain previously associated with the suicidal ideation (Canli 2014). The human body when infected with a parasite, bacterium or virus activates the immune system through inflammatory markers. These inflammatory markers activate the immune system in response to a certain type of pathogen (Canli 2014). Turhan Canli (2014) argues that "the immune response itself is the causal mechanism in depression"; for major depressive disorder the type of pathogen is significant because it plays an important role in the causality of the disease (Canli 2014).

\section{Criminological Aspects}

Having a suicidal behavior, the perpetrator of the filicide is overwhelmed by a state of uncertainty, spiritual uncertainty, uncontrollable desires of the criminal unconscious, and the desire for vengeance, concluding the accounts with the world, the family, and the whole of society, a vindictive priority for himself to free himself from the quake of inner aggression. The suicidal ideation finds in the destruction drive and the death drive way to curb the suffering and the unbearable sense of guilt, which in moments of lucidity causes the anguish and the psychic fall of the individual. Suicide becomes a goal for the perpetrator of the filicide. The existence of the suicidal plan precedes the intention of making the filicide and marital crime (the case of the filicide and marital murder in Brasov, 2018, when a man, after a suicide attempt, kills his wife and two minor children but survives and does not commit suicide after the committing the criminal act; the case of the Pitesti filicide in 2018, when a man affected by the 
separation from his wife shot his child for three and a half years, and then committed suicide; the case of Andreea Yates, Houston 2001, which, although after several suicide attempts, mill to avoid harming the children, remaining unsupervised by the husband, succeeds on the 20th of June in a single hour to drown the five children in the bath tub). "The essential element of a personality disorder is a durable pattern of internal and behavioral experience that deviates considerably from the requirements of an individual's culture and manifests itself in at least two of the following areas: knowledge, affectivity, interpersonal functioning, or impulse control" ( DSM-IV-TR, 2003, p. 686).

The sociological analysis of the filicide presents the risk factors that can cause marital killing and violence as the deterioration of family relationships, job loss, diminishing economic income, social isolation of the perpetrator, humiliation and dissatisfaction in marital life, age and progressive illness, the provocative attitude of the victim (especially in case of accidental filicide), personality disorders, low occupational status, divorce, alcohol consumption (Balica 2010). Behavioral disorders caused by alcohol consumption can destabilize socio-familial life. After consuming alcohol sometimes the individual can feel a bad state, the brain opposes the toxic effects caused by the substance that invades the body. Alcohol passes from the mouth to the stomach where the ethanol is transformed into acetaldehyde, and then into the liver where the metabolic process takes place. These decomposition of substances can influence and surprise the individual's body negatively, excess alcohol consumption can lead to nausea and vomiting, the metabolism of alcohol being incapable and insufficient to take up and transform toxic substances. If the body manages to experience nausea and vomiting in the case of excessive alcohol consumption, the effect of brain alert, in the case of inner aggression, controlling the functions of the being dominated by the destruction drive, the only way of defense is the deliberate unloading of violence of Id, an Id desfigured by hatred and the spontaneity abyssal feelings.

Incapable of adapting to society, the perpetrator is considered the victim of social rejection, the social and family environment adopts a position of disapproval of inappropriate behavior (alcohol, drugs, domestic violence). The suicidal ideation present in the aggressor's being is also determined by the stigmatizing position that the perpetrator encounters in the community (Tănăsescu 2012a). In conjugal violence, the life partner becomes unjustifiably the subject of aggression. The life partner (wife) is the one who offers confidence and emotional attachment, has dealt with the education of children, a complex attachment through which family life evolves positively. If the partnership breaks down (the wife leaves the marital residence and divorces), the perpetrator of the filicide sees that his existential failure has been caused by this rupture, the vindictive feeling turns into the reflection and reasoning of the crime, being a way of surviving with himself until he finishes transition to criminal act. Analyzing the function of psychoanalysis in criminology developed by Lacan's theory, Stephen Costello considers the passage to the act as impulsive acts of violent and criminal nature, which sometimes mark the onset of an acute psychotic episode (Costello 2017). The passage to act means the idea of homicide transformed into a criminal act, an intention that goes from the symbolic world and materializes into the real world then producing legal effects.

Filicide is not just an antisocial act sanctioned by law with the execution of a custodial sentence, but also represents the dramatic image of a family, in the midst of a community unable to prevent the passage to the act, an image that describes both the act provided by the criminal law and the stages that go through the perpetrator's guilt until the time of the crime. Psychological, religious and socio-economic issues are important when we analyze the crime etiology, the way in which the deed was committed, or when the psycho-legal forensic expertise discovered a diminished discernment, a personality afflicted by certain mental disorders (Tănăsescu 2012c). The perpetrator's guilt is described by the intellectual factor (discernment, conception of the deed, reflection and reasoning, justification and arguments in favor of crime, procedure, construction and premeditation of the criminal situation), the volitional factor (the manifestation of the inner force of the criminal ego pushed unconsciously to overcome any inhibition moral - destruction of the Superego - for the realization of the deed) and the affective factor - emotions of the unconscious released for intense experiences, catharsis (Atkinson, Atkinson, Smith, Bem 2002). The will to 
commit the filicide is born from the idea of homicide and suicide, but it is also pushed and caused by the criminal unconscious, who represents the resource of the destruction drive and of the death drive. Whenever a family member or a child is abused, the therapist or teacher must report the case to the local or governmental institution responsible (Davies and Frawley 2017).

\section{Psychoanalytic aspects}

By the drive Freud understands those forces that exist behind the tensions of Id's needs (Freud 2014). Through these drives the Id determines the social ego to interact with the outside world, but to satisfy in the first place the innate needs of the person. The drives become the physical requirements imposed on psychic life (Freud 2014). By destroying things, by social withdrawal, to protect the individual from existential suffering and dissatisfaction, by dissolving relationships with close relatives and professional relationships, the destruction drive leads the being to the inorganic state (Freud 2014) transforming into a death drive. It tends to return to a state before life, which is lifeless (the primordial absence) is supposed to precede the appearance of life (the essential presence). The destruction drive acts contrary to the love drive. The purpose of the love drive is to preserve and maintain the being in life, to keep in touch with the outside world, and to bring existential satisfaction to the social ego. Libido, as the available energy of Eros (Freud 2014), as the positive energy of the love drive, is present in Ego-Id but also in Superego. Ego tries to transfer libido investments to objects, only when someone is completely in love, the libido is transferred to the object and the object is somewhat in place of the Ego (Freud 2014 ). The philicide perpetrator reveals by suicidal ideation and intent that he has accumulated too much aggression within him that will cause behavioral change and stimulate self-destructive energy. Inhibiting the Superego, unleashing the courage of the moral court, will gradually cause the exhaustion of the social ego and the consumption of the life drive that is the death of libido; the individual dies because of his own internal conflicts (Freud 2014). In the Psychoanalysis Compendium, begun in the last year of life, Freud (2014) considers that libido has somatic sources, it flows to me from different organs and parts of the body. The perpetrator of the filicide having tense relationships in family life is supposed to be affected by anxiety, frustration, and alcoholic intoxication; major depressive episodes and antisocial personality disorder impair the content and the birth of pleasure, leaving the nakedness of feelings and without empathy. Inhibition of erogenous areas of the body, depletion of vital energy, consumption of libido through emotional, psychological and social blockade are factors that lead to the occurrence of suicidal behavior and the realization of conjugal violence. The victim becomes the object outside of the Id and the intention to satisfy the aggression drive. Through the will of the Ego (only this has the possibility of intercession) there is the possibility of destroying the Superego (the one who censures the excesses of the Id), instinctual drives freeing themselves from any inner barrier.

The conjugal murderer, who becomes the perpetrator of the filicide affected by the major depressive disorder, finds in his own being, in the darkness of the ancestral unconscious, the resource of aggressiveness, a sufficient amount of violence releases through interaction with the object of his victimization and opens the transfer of the destruction drive. The Superego, weakened by the effects of major depression, degrading inclinations, and choices without any essence of the Ego, no longer has the power to positively influence the decisions of making social acts; Superego does not have the force of Id's drives and cannot interrupt an immoral activity punished by criminal law; at the time of committing the crime, the moral court - Superego cannot intervene and prevent the materialization of the criminal act; a weak Superego cannot cause the self to commit suicide, cannot hurt its own being (the body) to interrupt aggression. The Id through the aggression drive blocks Superego and controls the decisions of the criminal ego. Without aggression, the Id remains ill and dissatisfied; his primitive instincts cannot tolerate this state.

David P. Celani (2014) in his book "Illusion of Love. Why the Maltreated Woman Returns to Her Abuser" analyzes the theory of psychoanalyst W.R.D. Fairbairn on the attachment of rejected and abused people to the person who caused them pain and suffering. Research has shown that children who have been forced to move from their abusive families have remained exceptionally 
attached to their parents, both at symbolic, imaginary and real levels. The children were emotionally disturbed and felt guilty for the situation, arguing that they were the ones who caused the negative family problems; their abusive and negligent parents were considered by the children to be good parents who always took care of their family. Sometimes "hundreds of refusals and rejections diminish the development of self-sentiment in the child".

\section{The Philosophical-Religious Interpretation of the Filicide}

From a religious point of view, it is important to see if the perpetrator has the capacity and the will to in himself the power to commit suicide to save his family from conjugal crime and filicide, although religion does not tolerate suicide regardless of the causes that caused it. This sacrifice is only in the interest of the family, this action saves the loved ones from the criminal act. The filicidal ideation (the thought of killing one's own child) is the trembling of the Superego, the moral court attempts at a moment of equilibrium of the social ego to push it to suicide before committing the filicide. The Superego assesses the dramatic situation and decides that it is better for the Ego to have the will and the power to destroy itself, loss of life is necessary and moral to prevent a terrible crime. The failure of suicide (attempted suicide) leads the evil towards the act. In the case of the murder in Brasov in 2018, the filicide perpetrator went to the monastery on the day of the act, he prayed, and told the investigators that he had become obsessed with the nature of the mystical act having a revelation. On his way home he tried to commit suicide with a knife. He failed and went to the home where he killed his wife and the two minors. In Andreea Yates, Houston, 2001, in the discussion with his psychiatrist, she said she wanted to commit suicide (tried several times but was saved) because he was afraid of killing his children. The filicide happened when the woman stayed unsupervised at home and drowned her five children in the tub.

In Genesis, chapter 22 of the Bible, Isaac offered for sacrifice, describes the three-day journey of Avraam to Mount Moriah. Avraam, at the call of God, takes his son Isaac and goes to Mount Moriah to kill him (the paternal filicide) and sacrifices it for the divinity. Sarra entrusts Avraam to her son Isaac, whom he loves very much and for whom he daily thanks to God for making possible his birth when no one ever thought it was likely to happen (Isaac is a miracle for the two parents). Sarra represents the image of the mother who entrusts her son to the life partner she trusts; the state of moral purity and innocence is presumed in the case of the mother of the victim of the filicide. Normally, no mother would entrust the child of a presumed murderer (the case of the Pitesti filibid in 2018, followed by the suicide of the perpetrator, the mother had total trust in her former partner, whom she had soon divorced, never considered possible killing the child). In his book on Trauma, Attachment and Family Constellations, Franz Rupert (2012) considers attachment to be a universal principle, surviving beings are reported to each other through attachment forces. The individual who participates in the attachment process, through language, feelings, thoughts, body touch, fusion of senses (smell, taste, vision, hearing) can leave an impression of indelible impression to another (Ruppert 2012). Attachment of a person to family members and especially to the mother is the fundamental form of human attachment (maternal or paternal filicide, matricide, paricide are considered cardinal crimes). Human attachments are emotional, all basic human feelings originate in the attachment. The emotional connections and experiences of people who create intersubjectivity can make it possible to translate into the situation of others (Ruppert 2012). In most cases, the aggressor and the victims live together, have the same rituals; the ancestral attachment has united their senses, the disappearance or death of a family member can cause a moral, emotional shock, or a mental trauma. In the case of revenge, the perpetrator of the filicide is aware of the emotional value of the criminal act, the moral prejudice he produces is immeasurable. "In the ideological sphere, vengeance is accompanied by a fantasy (conscious or unconscious) of having been seriously injured by someone and of obtaining satisfaction by injuring the aggressor" (Akhtar 2018). Sarra is attached to her son Isaac, but entrusts him with Avraam to go to Mount Moriah together. Avraam is attached to his son, but at the same time he loves God and wants to respect his will - Isaac's sacrifice. The inner conflict of Abraham is disturbing. He has to make the decision to kill the one born of the goodness of divinity, and at the same time feels exhausted and 
helpless for this deed. Avraam is influenced by faith, the universal voice of ethics, and is driven to commit the crime. Avraam does not dispute God's right to ask for an innocent child. Avraam feels guilty because he will not be able to accomplish the deed required by the divine voice. Sense of guilt does not show suicidal behavior, though Avraam is aware that if he kills his child at God's request, his life with Sarra will be just fear and trembling. The road to Mount Moriah spends him in mourning and distress (he is afraid of being considered weak and without faith, not to be cursed with the power to kill Isaac). Kierkegaard (2005) believes that without an eternal consciousness, inhabiting the being of man, without self-conscious awareness of eternal life, would only be despair. The interpretation of the Danish philosopher regarding the deed of Avraam proceeds from the situation of accepting destiny at the moment of calling the deity. His act is not absurd because he believed in the meaning of divinity. Avraam accepted the faith and left behind the worldly understanding (Kierkegaard 2005). "The meaning is the way, the road, and the bridge to the one who will come" (Jung 2011). The filicide in this case means the will of faith, the will to participate in the divine act - metanoia. When Avraam removes the knife, God prevents him from committing the filicide in the last moment; Overwhelmed by this attempt, Abraham has become old for eternity. "Who strengthened the arm of Avraam, who held up his right hand, lest he fall powerless? The one who sees this paralyzes" (Kierkegaard 2005).

\section{Conclusions}

Depression is a psychological disorder affecting about $7 \%$ of the general population (Schaffer and Rodolfa 2019, quoting Center for Behavioral Health Statistics and Quality, 2016). Studies of 442 men over a 20-year period have found an association between childhood maltreatment and later antisocial behavior as a function of MAOA-LPR genotype: the presence of both risk factors - the low- history of childhood maltreatment - doubled the risk for behavioral disorder, antisocial personality disorder symptoms, and other measures of aggression (Canli 2015). Major depression plays a significant role in producing suicidal behavior, as well as causing conjugal violence and filicide. There is not much objective explanation regarding the suicidal act of the conjugal murderer preceded by filicide, but all studies show the existence of major depressive disorder in the behavior of the perpetrator. Conjugal violence followed by filicide and the suicide of the perpetrator may be influenced by drug and alcohol consumption, poverty, divorce, job loss, but these factors are not the main cause of the crime. Social, cultural, economic factors can contribute to causing major depression, which, through its negative evolution, is turning into a significant disorder; the will of the killer finds in the major depression sufficient resources to conceive the suicidal ideation and the force required to execute the criminal act. The success of future research can lead to better treatment of the major depressive disorder, both as an infectious disease and as an emotional disorder. Through this treatment, we can avoid some of the difficult situations that lead to conjugal violence, in which one of the partners has the symptoms of major depression.

\section{References}

Akhtar, Salman. 2018. Sources of Suffering: Fear, Greed, Guilt, Deception, Betrayal and Revenge. Bucharest: Three Publishing House.

Aniţei, Mihai, Mihaela Chraif, Vlad Burtaverde, and Teodor Mihăilă. 2016. Personality Psychology Treaty. Bucharest: Three Publishing House.

Atkinson, Rita L., Atkinson Richard C., Smith, Edward E., Bem, Daryl J. 2002. Introduction to Psychology, Bucharest, Technique S.A. Publishing House.

Balica, Ecaterina. 2010. "The maternal and paternal filicide in Romania: trends and risk factors", in Romanian Sociology, Volume VIII, No 3.

Canli, Turhan. 2014. Reconceptualizing major depressive disorder as an infectious disease, Biology of Mood \& Anxiety Disorders, 4:10, doi: 10.1186/2045-5380-4-10.

Canli, Turhan. 2015. The Oxford Handbook of Molecular Psychology. New York: Oxford University Press.

Celani, David P. 2014. The Illusion of Love. Why the Battered Woman Returns to Her Abuser. Bucharest: Three Publishing House.

Costello, Stephen J. 2017. The Pale Criminal: Psychoanalytic Perspectives. Bucharest: Three Publishing House. 
Davies, Jody Messler, Frawley, Mary Gail. 2017. Treating the Adult Survivor of Childhood Sexual Abuse: A Psychoanalytic Perspective. Bucharest: Three Publishing House.

DSM-IV-TR. 2003. Diagnostic and Statistical Manual of Mental Disorders, edited by Aurel Romilă. The Free Psychiatric Association in Romania Publishing House.

Freud, Sigmund. 2014. About Psychoanalysis. Bucharest: Three Publishing House. German translation Daniela Ştefănescu.

Jung, Carl Gustav. 2011. The Red Book. Bucharest: Three Publishing House.

Kierkegaard, Soren. 2005. Fear and Trembling. Bucharest: Humanitas Publishing House.

Ruppert, Franz. 2012. Trauma, Bonding, Family Constellations, Trauma Psychotherapy. Bucharest: Three Publishing House.

Sartre, Jean-Paul. 2004. Being and Nothingness. Piteşti: Paralela 45 Publishing House.

Schaffer, Jack B., Rodolfa, Emil. 2019. ICD-10-CM: Casebook and Workbook for Students: Psychological and Behavioral Conditions, Bucharest: Three Publishing House.

Tănăsescu, Camil. 2012a. Criminology. Bucharest: Universul Juridic Publishing House.

Tănăsescu, Camil. 2012b. Judicial Psychology. Bucharest: Universul Juridic Publishing House.

Tănăsescu, Camil 2012c. Agreso-victimogene typologies. Bucharest: Universul Juridic Publishing House. 